\title{
Hologram Forensics on Forgery in Civil and Criminal Proceedings
}

\author{
Pavlovska Nataliia \\ PhD of Juridical Sciences, Associate Professor, Professor of Department \\ of Civil Law and Process of the National Academy of Internal Affairs, Kiev, \\ Ukraine ORCID ID 0000-0003-3311-0364 wwwpav@gmail.com

\begin{abstract}
Atamanchuk Volodymyr
PhD of Juridical Sciences, Chief of Department of Forensic Support and Forensic Expertise of the National Academy of Internal Affairs, Kiev, Ukraine ORCID ID 0000-0002-1464-7871 atamanchykvlad@ukr.net
\end{abstract}

\section{Kulyk Maryna}

PhD of Juridical Sciences, Associate Professor of Forensic Support and Forensic Expertise of the National Academy of Internal Affairs, Kiev, Ukraine ORCID ID 0000-0003-1373-6749 coolss777@ukr.net

\section{Strilets Halyna}

PhD of Judicial Sciences, Associate Professor of the Departament of Law of Prydunai Branch of Private Jointstock Company «Higher Educational Institution of Interregional Academy of Personnel Management», Izmail, Ukraine

ORCID ID 0000-0002-1067-0820 galinastrelets2018@gmail.com

\section{Kofanova Olena}

PhD of Juridical Sciences, Associate Professor of Forensic Support and Forensic Expertise of the National Academy of Internal Affairs, Kiev, Ukraine ORCID ID 0000-0002-0919-7570 kofanova_alena@ukr.net

\begin{abstract}
In expert practice, the issues of identifying holograms, establishing and comparing the protective properties of HSEs (holographic security elements) are often resolved.

Hologram examination consists of three stages.

The first stage involves visual control, during the second stage the microstructure is examined, while optical parameters are measured at the third stage. At each stage, the actual HSE data are identified, which together provide an answer to the questions raised. The study of holographic comparison methods is effective both for the study of a large number of objects and for diffraction of objects similar in their structure.
\end{abstract}

Keywords: determine the type of hologram, identify security level of the hologram, expertise of copyright objects and related rights, articles, specifications, datasheet. 
Introduction Identification, classification, and diagnostic tasks are resolved in the process of studying holograms.

Identification of holograms establishes:

- compliance of the hologram with its description - specifications, datasheet;

- holograms are replicated from the matrix supplied or from another matrix;

- compliance of the provided photo templates and layouts of the logo elements reproduced by the hologram;

- matching the original primary hologram to the rainbow hologram;

- compliance of the provided software with the synthesizing program.

Classification studies:

- determine the type of hologram;

- identify security level of the hologram.

The diagnostic study of holograms involves identification of the hologram production scheme. In our opinion, the hologram forensics should consist of several stages. First of all, a visual rapid test of the hologram shall be performed. Then the hologram type is established and the sequence of examinations depending on the possible method of forgery is determined [1].

A hologram is examined by comparing it with a reference sample. In this case the attention should be paid to:

- matching of the color scheme of the test hologram and the reference sample at the same illumination angles;

- presence of the holographic 'noise';

- accuracy of the logo recovery;

- type of the HSE attachment to the protected object (self-adhesive, hot stamping); 
- the number of image planes (mostly two or three planes, more of them are rarely used, because of the limitations on the depth and sharpness of the rainbow hologram);

- image depth (e.g. a $15 \times 15 \mathrm{~mm}$ hologram has a depth of 3 to $5 \mathrm{~mm}$ );

- presence of defects in the holographic image that may occur during the holographic copying of the original.

In addition, lesions, tears, cracks in the hologram are not allowed. Attention is also paid to the thickness of the hologram, the accuracy of its placement on the protected object, the structure of the material it is made of [2].

After that, the parameters are studied using laboratory methods. The following parameters are identified together with the reference sample: number of angles of the hologram (e.g., a complex hologram generally contains from 20 to 200 views, their number depends on the protected object, size of holographic images, color separations, materials used for recording; the playback quality of the microtext, nanotext and small parts of the image; HSE's diffraction grating modulus consists of a set of reflection gratings. The grating modulus spectrum determines how effectively the reflected light is decomposed into the spectrum. If viewed through a microscope with a magnification of 300 times, the holographic image will have the appearance of dark and light stripes. The diffraction grating modulus is the total width of the light and dark strips of the HSE; the width and relative position of the slits for a multifrequency rainbow hologram; the distance from the image of the slits to the hologram when the wave front is set to the specified curvature.

If encoded or hidden information is used in a hologram, it is decoded, identified, and analyzed to match the sample [3].

If necessary, additional studies of the hologram can be carried out, such as material control (glue/adhesives are selected so that the destruction of the hologram - complete or partial - occurs when peeling, heating and solvents are used; this renders it impossible to reuse or copy the HSE, optical study of the diffraction structure of the hologram. The study of holographic security marks by means of laboratory methods is conducted using standard optical devices (microscopes, photometers, spectrometers, etc.), special laser equipment, which identifies a complex image of the HSE and reads the latent image. A complex and latent 
image can not only be visually observed but also entered into a computer for further comparison with the reference sample. In this case, the image is examined on such crucial parameters as resolution, presence of three-dimensional images (for example, flat twodimensional image only, simultaneous coincidence of the foreground and background of 2D and 3D images, a fully three-dimensional image), the presence of color gamut, presence of mobility, available ink numbering on the surface of the hologram or laser numbering in the hologram, as well as a number of other parameters [4].

The requirement for the stability of the HSE's protective properties is recognized as the possibility of changing the appearance of the mark for at least one characteristic feature in case of unauthorized violation of its operating conditions. For example, when separating a security mark from a plastic card, it becomes completely or partially destroyed, exhibiting a decrease in resolution, violation of the color gamut, microtexts or micro-optical details in the image of the mark, non-reflection of the latent image, which is detected by a magnifying glass, microscope, laser device used for identifying holograms, and so on.

The stability of the protective properties of the HSE is ensured by the technology of manufacturing the mark in the form of a self-adhesive label. Hot stamping method, which in both cases ensures the destruction of the mark when trying to separate it [5].

In our opinion, in order to establish the authenticity of the hologram, it is advisable to put the following questions to the expert:

- whether a tag on the provided object is a holographic security mark; if so, what type (type) of HSE belongs to (hologram, kinegram, pixelgram etc);

- whether the test holographic sample meets the established standard;

- method of attaching the HSE to the protected object;

- whether the holographic security mark was exposed to unauthorized influence; if so, in what way;

- if a tag on the provided object is not a holographic security mark, then how is it made, what means were used to produce it;

- whether the equipment provided for the study was used to make the tag? 
For hologram forensics special laboratories have been created in the country's expert institutions. Research methods are developed and the possibilities of procedural permissibility of using lasers in court proceedings are considered. Familiarization with the practice of such laboratories has shown that they mainly conduct research on holograms that protect individual products from forgery and are used as seals for office equipment. Such research is conducted annually in the expert laboratories of the Security Service of Ukraine, dedicated expert institutions of the Ministry of justice in Ukraine [6].

Holographic security systems are based on the discoveries and achievements of modern optics and materials science. A hologram is a complex microstructure that comprises the visual perception of three-dimensionality of an image. Holographic information is recorded during the laser interference shooting. This technology makes it possible to obtain holographic elements with bright and high-quality images. Volume, iridescent color play, a large number of optical effects determines its significance.

Holographic protective elements combine the principle and action regardless of the retention method: these are relief microstructures with a size of about one micron and a depth of relief in the fraction of a micron. Light falling on such structures, as a result of diffraction and interference, splits into a spectrum forming a rainbow effect. In this case, the colour and shape of the image changes when the hologram is tilted or rotated [7].

Types of holograms:

- 3D holograms reproduce a three-dimensional image of a real object. To record them, you need a real object or its model at a scale of 1:1. Such holograms fully convey the brightness and three-dimensionality of objects however, their resistance to optical copying is not very high. 3D holograms are widely used to protect trade marks and enhance their image;

- A 2D hologram consists of several flat images that are visually located one after the other and deliver a three-dimensional effect. This type of hologram is protected from optical copying by introducing special graphic elements and optical effects into the structure of the GSE, so this type of hologram is used to protect goods, documents, and accountable forms;

- Dot-matrix - do not require the presence of the object and its model. The image delivers high brightness, contrast, and clarity that distinguishes it from other types. The 
presence of optical effects that are not available for other technologies makes holograms significant;

- combined holograms involve combining several technologies in one hologram.

The most effective protection can be achieved when additional security elements (holographic security elements) are included in the GSE [8].

- microtexts are texts embedded in a hologram with a font size of less than $0.1 \mathrm{~mm}$. Such text is invisible to the naked eye, and can only be read with a magnifying glass or microscope;

- guilloche and benday screens. The pattern consists of a complex interweaving of fine lines.

This pattern can be background, embedded in any element of the image, or superimposed on any part of the hologram [9]:

- latent image is not visible to the naked eye and is not perceived separately with a microscope;

- end-to-end numbering. Each holographic element has an individual number, made in marking ink that does not wash off, on a thermal transfer printer or by laser engraving;

- fractal structures. If you look at a fractal pattern under a microscope, you can see that it consists of a large number of small lines, which in turn consist of smaller ones. A simple example of a fractal structure is a snowflake;

- selective demetallization. The reflective metallized layer is removed from the specified sections of the holograms. In this way, a hologram may comprise a transparent image or inscription.

Hologramming methods [10].

Conclusions A self-adhesive label (application) is a holographic element that is applied to any object as a regular stick-on label, but when you try to remove it from the object, it is destroyed. Labels can be applied manually or using special tools. 
Hot stamping foil. Hot stamping foil consists of a polyester base on which a layer of protective varnish is applied, a metallized layer with a holographic pattern, an adhesive layer after pressing such HSE on the document, a thin (5 to 10 microns) layer of metallized varnish bearing holographic pattern is retained. Such a security element cannot be separated from the base and transferred to another document without compromising its integrity.

Lamination film. The holographic pattern is located on a transparent film that can be used for laminating documents. Conventional laminators can be used to apply such a film.

Holograms are used to:

- protect payment cards, letterhead papers against forgery;

- protect manufacturers' trademarks;

- certify the authenticity of products;

- control access to premises and facilities;

- give a bright look to advertising products.

\section{References}

1. Avdieieva H.K., 2006. Forensic examination of counterfeit audiovisual products (based on criminal case files). Monograph, ed. Professor V. Yu. Shepitko. Kharkiv: Pravo, available at http://dspace.nlu.edu.ua/bitstream/123456789/648/1/AvdeevaMono.pdf

2. The Law of Ukraine "On Distribution of Copies of Audiovisual Works, Phonograms, Videograms, Computer Software, Databases", available at https://zakon.rada.gov.ua/laws/show/1587-14

3. Lelotko Yu. I. The official web portal of the Verkhovna Rada of Ukraine. Available at http://elar.naiau.kiev.ua/jspui/bitstream/123456789/9057/1/\%D0\%A1\%D0\%A3\%D0 $\% 94 \%$ D0\%9E\%D0\%92\%D0\%9E$\% \mathrm{D} 0 \% 95 \% \mathrm{D} 0 \% 9 \mathrm{~A} \% \mathrm{D} 0 \% \mathrm{~A} 1 \% \mathrm{D} 0 \% 9 \mathrm{~F} \% \mathrm{D} 0 \% 95 \% \mathrm{D} 0 \% \mathrm{~A} 0 \% \mathrm{D} 0 \% \mathrm{~A} 2 \% \mathrm{D} 0 \% 9 \mathrm{D} \% \mathrm{D} 0$ \%90_p218-220.pdf

4. The Order No. 591 of the Ministry of Internal Affairs of Ukraine dated 17/07/2017. The official web portal of the Verkhovna Rada of Ukraine. Available at https://zakon.rada.gov.ua/laws/show/z1024-17 
5. The draft Law of Ukraine "On Amendments to Certain Legislative Acts of Ukraine", registration No. 2565 of 10/12/2019. The official web portal of the Verkhovna Rada of Ukraine. Available at http://w1.c1.rada.gov.ua/pls/zweb2/webproc4_1?pf3511=67591

6. Chvankin V.A. Osobennosti otdel'nyh kriminalisticheskih issledovanij produkcii, obladajushhej priznakami kontrafaktnosti : posob. [Features of individual forensic studies of products with signs of counterfeiting: handbook.] / V.A. Chvankin, A.L. Poskreblo. - Minsk, 2005.

7. Chvankin V.A. Praktichni aspekti kriminalistichnih doslidzhen' produkciï z oznakami kontrafaktnosti : metod.rek. [Practical aspects of forensic research of products with signs of counterfeiting: method. recomm.] / V.A. Chvankin, A.V. Kofanov. - K. : KIJ, 2008.

8. Chvankin V.A. Metodika tehniko-kriminalisticheskogo issledovanija poligraficheskogo oformlenija i jelementov zashhity magnitnyh i opticheskih nositelej informacii, soderzhashhih ob\#ekty intellektual'noj sobstvennosti, $v$ celjah ustanovlenija tehnicheskih priznakov kontrafaktnosti [Methodology of technical and forensic research of printing design and protection elements of magnetic and optical information carriers containing intellectual property objects, in order to establish technical signs of counterfeiting] / V.A. Chvankin // Kriminalisticheskoe obespechenie rassledovanija i raskrytija prestuplenij: nauch. tezisy, vystup. $i$ soobshh, Kyiv, 30 apr. 2010 . / Kyiv. nac. un-t vnutr. del Ukrainy. - K.: KIJ, 2010. - P. 150-155.

9. Practical Aspects of Appointment of Judicial Expertise in the Field of Intellectual Property (Expertise of Copyright Objects and Related Rights, Articles, Computer Programs and Databases). URL: https://doi.org/10.32370/IA_2019_09_12

10. Forensic Examination of Packaging with Indications of Counterfeiting Present on Optical Media in Civil and Criminal Proceedings. URL: https://doi.org/10.32370/IA_2020_01_9

\section{Translation of the References \#6-8 to the original language}

6. Чванкин В.А. Особенности отдельных криминалистических исследований продукции, обладающей признаками контрафактности : пособ. / В.А. Чванкин, А.Л. Поскребло. - Минск, 2005.

7. Чванкін В.А. Практичні аспекти криміналістичних досліджень продукції $з$ ознаками контрафактності : метод.рек. / В.А. Чванкін, А.В. Кофанов. - К. : КИЙ, 2008.

8. Чванкин В.А. Методика технико-криминалистического исследования 
полиграфического оформления и элементов защиты магнитных и оптических носителей информации, содержащих объекты интеллектуальной собственности, в целях установления технических признаков контрафактности / В.А. Чванкин // Криминалистическое обеспечение расследования и раскрытия преступлений: науч. тезисы, выступ. и сообщ, Киев, 30 апр. 2010 г. / Киев. нац. ун-т внутр. дел Украины. - К.: КИЙ, 2010. C. $150-155$. 